\title{
The first report of diplostomiasis from cultured rainbow trout (Oncorhynchus mykiss) in Turkey
}

\author{
Meriç Lütfi AVSEVER ${ }^{1}$, Mevlüt Melih SELVER ${ }^{2}$, Öznur YAZICIOĞLU ${ }^{2}$, Erol TOKŞEN ${ }^{3}$, \\ Sami TAY ${ }^{2}$, Gülçin ERDAL ${ }^{2}$, Münevver Ziynet GÜNEN ${ }^{2}$
}

\begin{abstract}
${ }^{1}$ Aksaray University, Eskil Vocation of High School, Laboratory and Veterinary Sciences, Aksaray; ${ }^{2}$ Bornova Veterinary Control Institute, Fish Diseases National Reference Laboratory (NRL); ${ }^{3}$ Ege University, Faculty of Aquaculture, Department of Parasitology, İzmir, Turkey.
\end{abstract}

\begin{abstract}
Summary: Metacercariae of the Diplostomum spp., the cause of Larval Eye Diplostomiasis (LED), are located in the lenses of the eyes of fresh water fish and cause degeneration, lens opacity and blindness as disease progresses. Feed uptake is hindered in fish with failing eyesight causing loss of apetite and mortality becomes inevitable with the onset of secondary diseases. Freshwater molluscs and waterfowl have an important role in the fast spread of the disease to nearby farms. In this work, a total of 534 trout samples obtained from 24 farms located in southeastern Turkey were examined for LED. Histopathological findings were evaluated in thirty fish with lens opacity in varying degrees. Also these fish were examined in terms of bacterial agents as well. As a result of this work, Diplostomum spp. metacercariae were found to be prevalent in the lenses of fish. In fish with marked lens opacity, focal to extensive subcapsular cataract was observed. Cataract lesions included abnormal proliferation of the lens epithelium at the site of capsular rupture, often followed by degeneration, fragmentation and liquefaction of adjacent cortical lens fibers. Additionally, Lactococcus garvieae was also isolated in 10 of 24 farms.

Keywords: Diplostomiasis, Rainbow trout.
\end{abstract}

\section{Türkiye'deki gökkuşağı alabalıklarında (Oncorhynchus mykiss) ilk Diplostomiasis bildirimi}

Özet: Larval Göz Diplostomias (LED)'in etkeni olan Diplostomum spp.'nin metaserkerleri tatlı su balıklarının göz lenslerinde yerleşerek hastalık ilerledikçe dejenerasyon, lenslerde opasite (katarakt) ve körlüğe yol açmaktadır. Görme yetisini kaybeden balıklarda yem alımı engellenmektedir ve bu durum iştah kaybına yol açmakta ve sekonder enfeksiyonların da gelişmesi ile birlikte mortalite kaçınılmaz hale gelmektedir. Tatlı su yumuşakçaları ve su kuşları hastalığın yakın çiftliklere hızla yayılmasında önemli role sahiptir. Bu çalışmada, Türkiye'nin güneydoğusunda bulunan 24 balık çiftliğinden toplanan 534 alabalık örneği LED açısından muayene edilmiştir. Değişen derecelerde lens opasitesi gösteren 30 balıkta histopatolojik bulgular değerlendirilmiştir. Ayrıca, bu balıklar bakteriyel etkenler açısından da incelenmiştir. Bu çalışmanın sonucunda, Diplostomum spp. metaserkerleri balıkların lenslerinde yaygın olarak tespit edilmiştir. Belirgin lens opaklı̆̆ görülen balıklarda fokalden yaygına değişen subkapsüler katarakt gözlemlenmiştir. Katarakt lezyonları lens epitelinin kapsüler ruptur bölgesinde anormal proliferasyonu ile sıklıkla bunu izleyen dejenerasyon, fragmentasyon ve bitişik kortikal lens liflerinde sıvılaşma belirtilerini içermektedir. Buna ek olarak, 24 çiftliğin 10'unda Lactococcus garvieae de izole edilmiştir.

Anahtar sözcükler: Diplostomiasis, Gökkuşağı alabalığı.

\section{Introduction}

Diplostomiasis is an important infection in fresh water fish, especially in trout and carp. Diplostomum spp. are oviparous and their eggs which are $0.1 \times 0.006 \mathrm{~mm}$ in size are released into water with the faeces of waterfowl. In the infection caused by the metacercariae of Diplostomum spp. bloody foci appear in the head of the fish. Especially the gills are seen to be covered with blood. Fish smaller than $5 \mathrm{~cm}$. with these symptoms die within 15-30 minutes. Death is the result of aspphexia due to degenerations in the branchial veins and anoxia in the pericardium $(1,3,15)$.
Buchmann and Uldal (4) have reported eye degenerations to an extent of $80-100 \%$ in rainbow trout (Onchorynchus mykiss) and these degenerations were especially in the lens and rarely in vitrious humor and in frontal section of the eye. The most notable sign of Diplostomum spp. infection in fish has been described as cataract formation. The main factor influencing the severity of cataracts is the number of parasites in the lens (2).

Bacterial agents also infect the susceptible fish through the defect formed by the parasites, increase the severity of the disease causing systemic weakness in the fish and make way for new parasitic invasions (2). 
The aim of this study was to notify the occurence of LED in trout stocks for the first time in Turkey with parasitological and histopathological methods and to draw attention to importance of the disease.

\section{Materials and Methods}

A total of 534 rainbow trout (O. mykiss) weighing 80-100 g (92 \pm 1 g SD) obtained from 24 farms in the Southeastern part of Turkey (Gaziantep, Şanlıurfa) were examined in 2012, August. Also, thirty fish with lens opacity in varying degrees were exposed to histopathological examination. Cages were located in the Firat (Euphrates) river, on the Turkish side. They were 10-15 $\mathrm{m}$ away from the shore, $5-10 \mathrm{~m}$ in depth with a capacity for 10.000-15.000 fish. Water temperature was $15-16{ }^{\circ} \mathrm{C}$ and $\mathrm{pH}$ was between 7.7-8.3.

Eyeballs of fish samples were dissected and lenses were seperated into petri dishes with $0.9 \%$ physiological saline solution. These lenses were examined under light microscope. Identification of the parasites were carried out according to Markevich (15) and Gusev (8). The prevalence, parasite range and mean abundance of the parasite were calculated (5).

Fish with lens opacity in varying degrees were exposed to histopathological examination. Both eyeball was removed from every fish, transected horizontally and fixed in $10 \%$ neutral buffered formalin. After processed by standart histological techniques, samples were embedded in parafin wax, sectioned at 4-5 $\mu \mathrm{m}$ thickness and stained with hematoxylin and eosin (HE) to be examined under a light microscope (14).
For bacterial examination, ocular fluid, liver, sppleen and kidney samples were streaked onto Trypticase-Soy Agar (TSA, LABM), blood agar (LABM) and incubated at $25^{\circ} \mathrm{C}$ for 48 hours. After incubation, colonies were purified and identified according to their physiological, biochemical and enzymatic characteristics $(2,10)$.

\section{Results}

Diplostomum spp. metacercariae were obtained from 534 samples in varying numbers. The disease was observed to cause serious economic losses. The greatest contribution to the spread of this disease was the lack of appropriate preventive measures targeting the life cycle of this parasite. Some of the risk factors detected in the field were the presence of water fowl around the premises (Figure 1A), gaps on the cages where these birds could catch infected fish (Figure 1B), dead fish left unpicked in the water (Figure 1C), water molluscs in the cages (Figure 1D) and environmental pollution. The prevalence and parasite range of Diplostomum spp. metacercariae were presented in Table 1. Macroscopic appearence of fish was supplied in Figure 2. Diplostomum spp. metacercariae were detected in varying numbers within the lens of the eyes in all fish examined (Figure 3). The intensity of the infection by parasites was different in both eyes and in only a few fish, one eye was affected. Parasites were not found in other parts of eye. Lenses with small numbers of parasites showed no detectable change other than metacercarial larvae surrounded by a cavity and

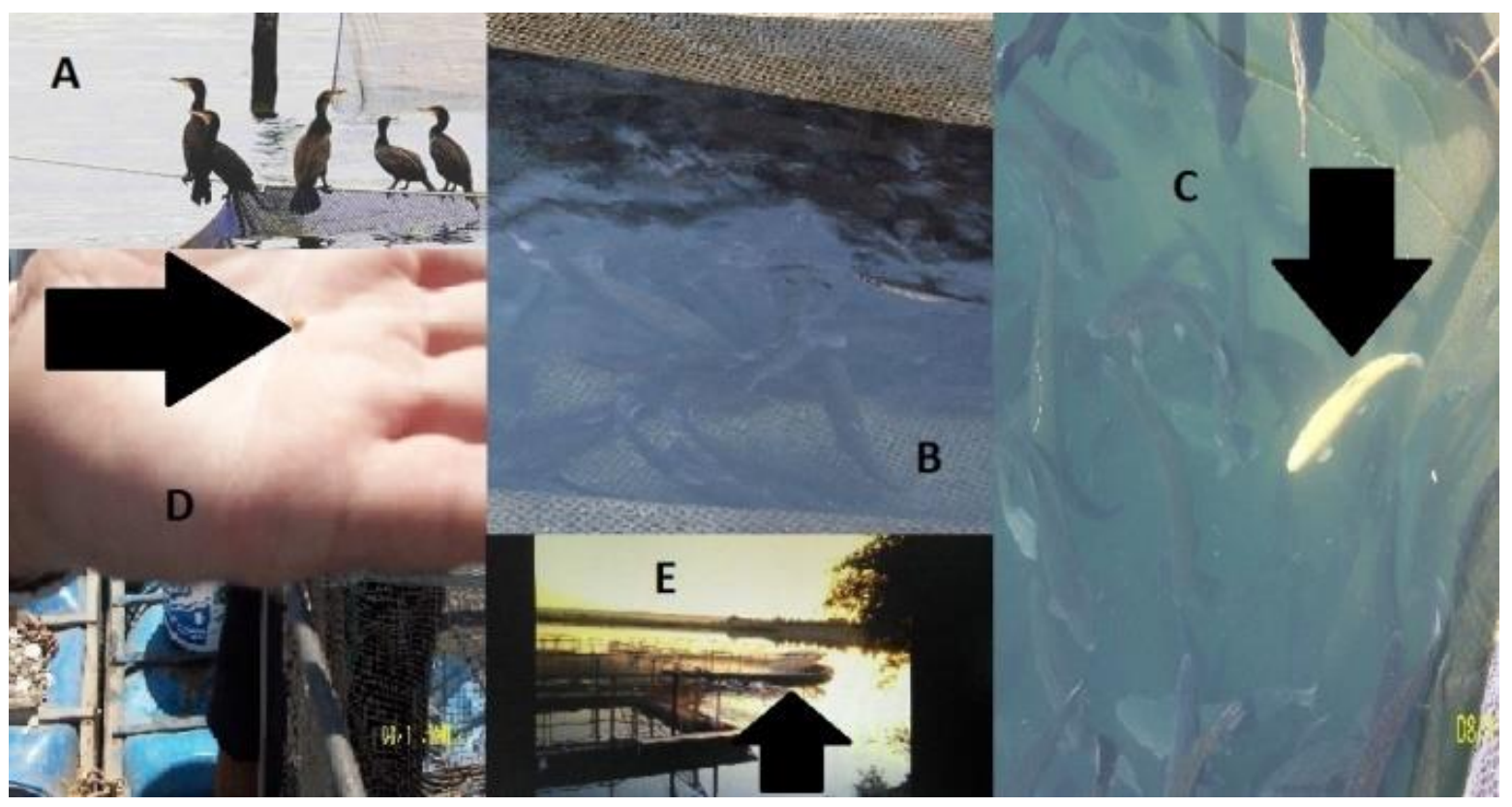

Figure 1. Photographs from the premises where Diplostomiasis was detected. A. Water fowl around the cages. B. Gaps on the cages where birds could catch infected fish. C. Dead fish (arrow) left on the water. D. An example of molluscs (arrow) on the sides of cages. E. Environmental pollution (arrow).

Şekil 1. Diplostomiasisin tespit edildiği sahadan alınan fotoğraflar. A. Kafeslerin etrafındaki su kuşları. B. Ağ kafeslerinde su kuşlarının enfekte balıkları yakalayabileceği boşluklar. C. Ölü balıkların (ok) suda bırakılması. D. Ağ kafeslerinin kenarlarından bulunan su sümüklülerine (ok) bir örnek. E. Çevresel kirlilik (ok). 
frequently dispersed throughout cortex of the lens without an inflammatory response. In some lenses, there were also a capsular ruptur and the slight leakage of the lens material from the damaged capsule into the aqueous or vitreous humor. In heavily infected fish by numerous metacercariae with marked lens opacity, focal to extensive subcapsular cataract was prevalent. Cataract lesions included abnormal proliferation of the lens epithelium at the site of capsular rupture (Figure 4), often followed by degeneration, fragmentation and liquefaction of adjacent cortical lens fibers. These lesions occurred not only at the entry site of parasites from the lens capsule (Figure 5) but also along their migration route in the cortical region of the lens (Figure 6). Also, the migration of parasites left a number of cavities containing eosinophilic liquefactive lens material along their passing route. Solitary to confluent bladder cells were frequently observed adjacent to the proliferating lens epithelium (Figure 4, 6). In some lenses with advanced lesions, the formation of fibrous tissue at the site of capsular rupture association with the reparation was evident. This formation was evidenced by the presence of fibroblast-like cells and was enclosed within the original or duplicated capsule at the site of rupture. The overlying lens capsule was thickened and folded (Figures 3, 4). Additionally, L. garvieae was isolated from 10 of 24 farms $(41.66 \%)$.

Table 1. The prevalence and parasite range of Diplostomum spp. metacercariae in farms.

Tablo 1. Çiftliklerdeki Diplostomum spp. metaserkerlerinin prevalans1 ve parazit ortalamas1.

\begin{tabular}{ccccc}
\hline \multirow{2}{*}{$\begin{array}{c}\text { Number } \\
\text { of farm }\end{array}$} & $\begin{array}{c}\text { Number } \\
\text { of fish }\end{array}$ & $\begin{array}{c}\text { Prevalance } \\
(\%)\end{array}$ & \multicolumn{2}{c}{ Number of parasites } \\
\cline { 4 - 5 } & 30 & 86.7 & 0 & Min. \\
\hline 1 & 42 & 100 & 5 & $>100$ \\
2 & 30 & 100 & 5 & 75 \\
3 & 20 & 85 & 0 & 33 \\
4 & 10 & 100 & 5 & 50 \\
5 & 19 & 47.4 & 0 & 17 \\
6 & 32 & 100 & 9 & $>100$ \\
7 & 15 & 100 & 17 & $>100$ \\
8 & 35 & 100 & 7 & $>100$ \\
9 & 32 & 93.3 & 0 & $>100$ \\
10 & 30 & 100 & $*$ & $*$ \\
11 & 20 & 95 & 0 & $>100$ \\
12 & 16 & 100 & $*$ & $*$ \\
13 & 30 & 100 & $*$ & $*$ \\
14 & 20 & 100 & $*$ & $*$ \\
15 & 30 & 100 & 12 & $>100$ \\
16 & 30 & 100 & 35 & $>100$ \\
17 & 15 & 100 & $*$ & $*$ \\
18 & 30 & 100 & 19 & $>100$ \\
19 & 18 & 72.2 & 0 & 11 \\
20 & 10 & 100 & 4 & 66 \\
21 & 10 & 100 & 3 & 80 \\
22 & 10 & 100 & 9 & 84 \\
23 & 534 & 95.4 & 0 & $>100$ \\
24 & & & & $*$ \\
\hline
\end{tabular}

* More than 100 parasites in all the fish (Min., Max. > 100).

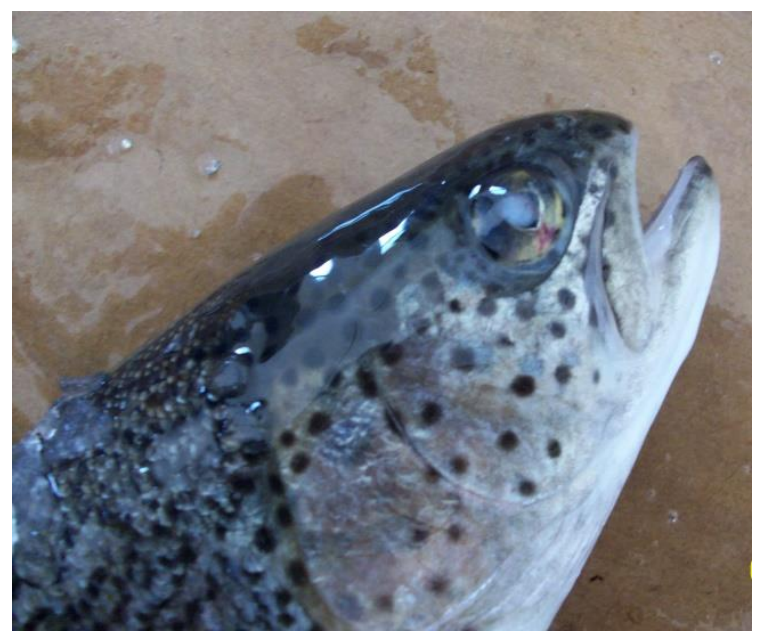

Figure 2. Severe opacity in the eyes due to Diplostomum spp. Metacercariae.

Şekil 2. Gözde Diplostomum spp. metaserkerlerine bağlı ciddi oposite.

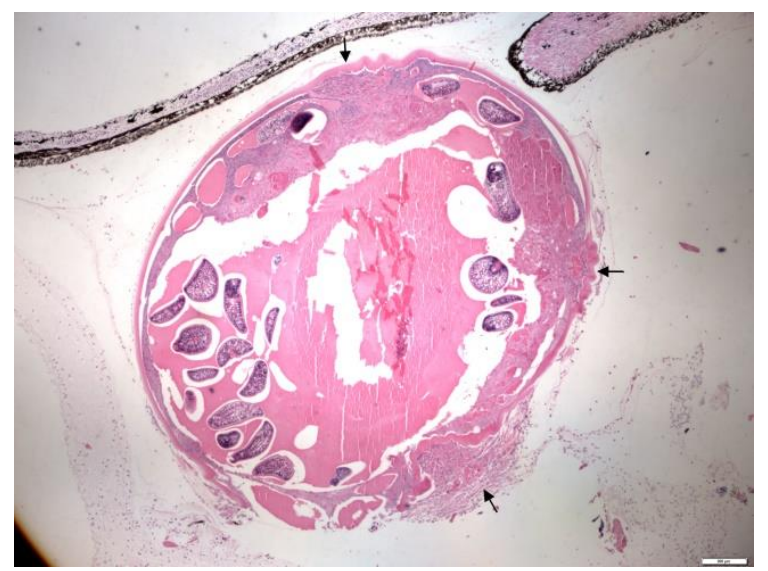

Figure 3. Lens of a rainbow trout showing numerous metacercarial larvae. Entry sites of parasites into the lens (arrows). HE. Bar $=200 \mu \mathrm{m}$.

Şekil 3. Gökkuşağı alabalığı lensinde çok sayıda metaserkel larva. Parasitlerin lense giriş bölgeleri (oklar). HE. Bar $=200 \mu \mathrm{m}$.

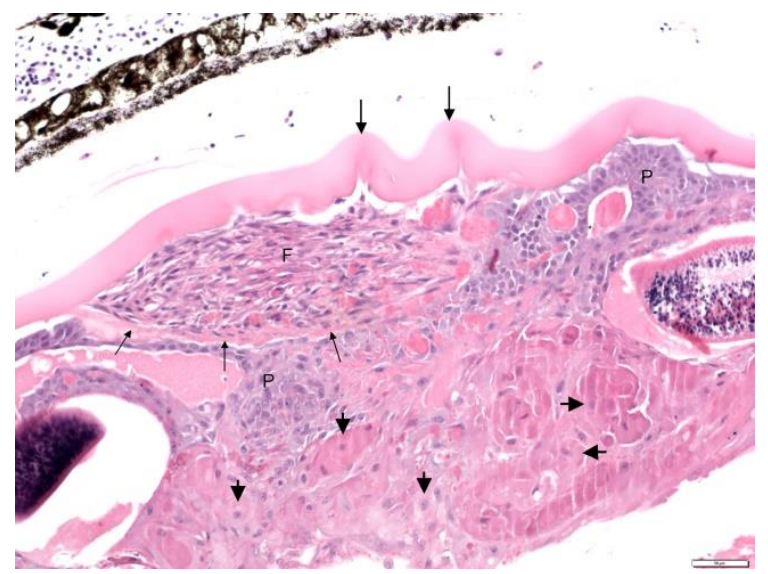

Figure 4. Demonstrates proliferating lens epithelium (P), thickened and folded lens capsule (long arrows) with duplication (thin arrows), the formation of subcapsular fibrous tissue (F) and bladder cells (short arrows). HE. Bar $=50 \mu \mathrm{m}$.

Şekil 4. Lens epitelyumunda proliferasyon (P), lens kapsülünün dublike olarak (ince oklar) kalınlaşıp kıvrılması (uzun oklar), subkapsüler fibröz doku oluşumu (F) ve kese hücreleri (kısa oklar). HE. Bar $=50 \mu \mathrm{m}$. 

Münevver Ziynet Günen

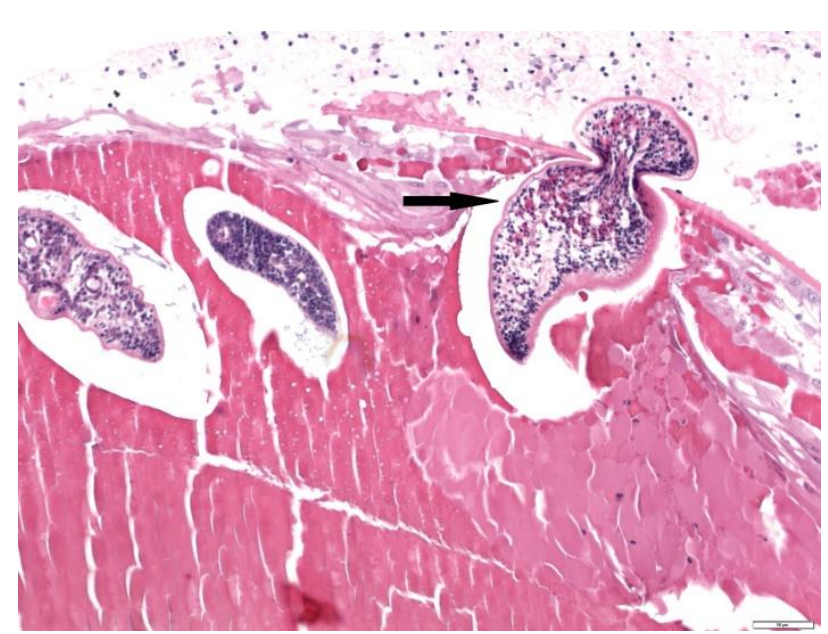

Figure 5. The entry of a Diplostomum metacercariae (arrow) from the capsule into the lens. HE. Bar $=50 \mu \mathrm{m}$.

Şekil 5. Diplostomum metaserkerinin (ok) kapsülden göz lensine girişi. HE. Bar $=50 \mu \mathrm{m}$.

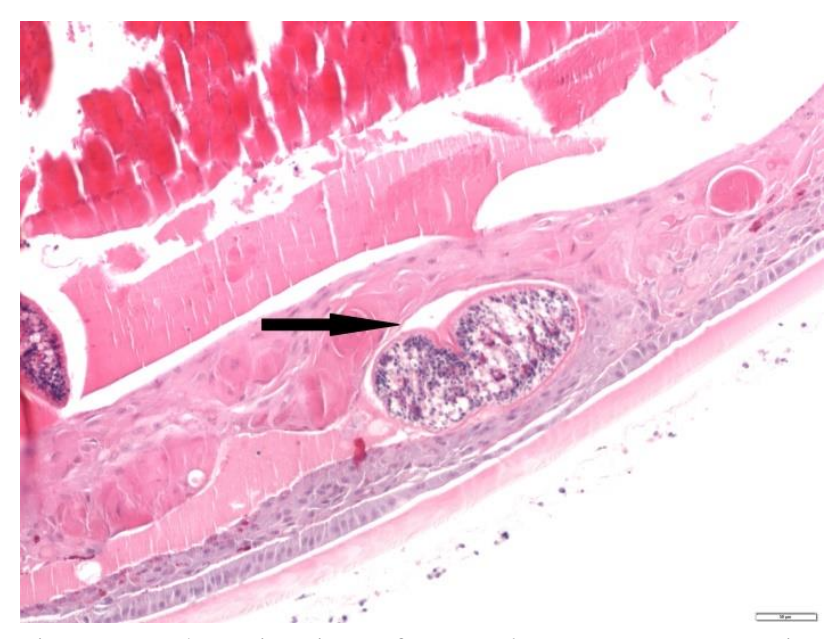

Figure 6. The migration of a Diplostomum metacercariae (arrow) within the lens, proliferating lens epithelium and bladder cell formation. HE. Bar $=50 \mu \mathrm{m}$.

Şekil 6. Lens içindeki Diplostomum metaserkerinin (ok) göçü, lens epitelyumunda proliferasyon ve kese hücreleri oluşumu. HE. Bar $=50 \mu \mathrm{m}$.

\section{Discussion and Conclusion}

In this work, a total of 534 trout samples from 24 farms in the southeastern part of Turkey were examined for LED. During the study, Diplostomum spp. metacercariae were found to be prevalent in the lenses of fish. Lens opacity or blindness were not encountered in every fish sample with metacercariae. These symptoms were more commonly found in fish positive for metacercariae in the eyes and which also were reared under unsatisfactory conditions and were positive for pathogenic cocci. This work was carried out during summer months and water temperature was $15-16{ }^{\circ} \mathrm{C}$ a period when coccal infections show a rise in incidence (10).
Karvonen (12) detected that cataract intensity increased significantly with parasite burden. Evans et al. (7) reported that parasitic cataract occurred when metacercariae counts exceed 40 individiuals per eye, depending on fish size. In this study, cataract lesions were observed in heavily infected fish with metacercariae, as described in previous studies $(9,11)$. Pathology associated with parasite has been described as degeneration and necrosis of the epithelial cells surrounding the injured lenses, forming the basis of mature cataract (17). Histopathological findings observed in lenses with marked opacity in our study were also correlated with the findings reported previously in rainbow trout by some authors $(13,19)$. However, Shariff et al. (19) reported that the proliferating lens epithelium did not show any marked resemblance to the fibrous tissue.

LED was previously reported in various fish species in Turkey $(6,9,18,20)$. These reports, however were limited to natural fish stocks in rivers and lakes. The number of affected fish were much lower in these studies. Also, the economic value of natural fish stocks in lakes and rivers is hardly comparable to the value of farmed stocks. This existence of this disease in large trout stocks in southeastern Turkey can cause serious economic losses. Thousands of tonnes of fish becoming anorexic, blind and eventually dying should be considered to fully comprehend the severity of the economic damage. This situation can even be worse if it spreads to stocks of The Central Anatolian region neighboring southeastern provinces, which have huge stocks of trout. Previous research also supports the fact that cataract is the cause of huge economic losses in cultured fish. For example, Menzies et al. (16), estimated the losses due to cataract to be around 27.9 million Euros in salmonids cultured in Norway.

In this study, L. garvieae was the only pathogenic bacteria detected in bacteriological examinations. Good farming practices and strong constitution in fish may delay the onset of opacity and blindless also they can not prevent the metacercariae from infecting the eyes. Thus, the fish can reach the harvest period without becoming blind and cachexia.

In conclusion, Diplostomiasis was detected for first time in trout stocks in Turkey with parasitological and histopathological methods. As diplostomiasis is rapidly spread through waterfowls, control measures to be taken in these farms are also necessary to prevent the spreading to trout farms in other parts of Turkey, such as Central Anatolia, Black Sea, and even Aegean Region. It was thought that Lactococcus infection found in the fish with diplostomiasis increased the intensity of the parasitic invasion. 


\section{References}

1. Arda M, Seçer S, Sareyyüpoğlu M (2010): Balık Hastalıklarl, 1. bask1, Medisan Yayınevi, Ankara, 104109.

2. Austin B, Austin DA (2012): Bacterial Fish Pathogens: Disease of farmed and wild fish, 5th edition Sppringer, New York, 978-94-007-4884-2pp.

3. Bykhovskaya-Pavlovskaya IE, Gusev AV, Dubinina MN, et al. (1962): Key to Parasites of Freshwater Fish of the U.S.S.R. İzdatel'stvo Akademi Nauk S.S.S.R., Moskova-Leningrad, 200-605.

4. Buchmann K, Uldal A (1997): Gyrodactylus derjavini infections in four salmonids: comparative host susceptibility and site selection of parasites. Dis Aquat Org, 28, 201-209.

5. Bush AO, Lafferty KD, Lotz JL, et al. (1997): Parasitology meets ecology on its own terms: Margolis et al. revisited. J Parasitol, 83, 575-583.

6. Dorucu M, Ispir Ü (2001): Seasonal variation of Diplostomum spp. infection in eyes of Acanthobrama marmid in Keban Dam Lake. EÜ Su Ürünleri Dergisi, 3, 301-305.

7. Evans RS, Heckmann RA, Palmieri J (1976): Diplostomiasis in Utah. Utah Acad Proc, 53, 20-25.

8. Gusev AV (1985): Class Monogenea, In: O.N. Bauer, (Ed.), Keys to Parasites of the Freshwater Fish Fauna of the USSR, (Parasitic Metazoa), Leningrad Publishing House Nauka, Leningrad, Russian, 2, 10-253.

9. Gül A, İspir Ü, Türk C, et al. (2014): Investigation of Diplostomum spp. Metacercariae in Some Cyprinids from Murat River (Genç Area), Bingöl, Turkey. TurkJANS, 1, 547-551.

10. Holt JG, Krieg NR, Sneathm PHA, et al. (1994): Bergey's Manual of Determinative Bacteriology, 9th edn. Baltimore, 1994, MD: Williams and Williams.

11. Karvonen A, Seppala O, Valtonen ET (2004): Eye flukeinduced cataract formation in fish: quantitative analysis using an ophthalmological microscope. Parasitology, 129, 473-478.
12. Karvonen A (2012): Diplostomum spathaceum and related sppecies. In: (Eds) Woo, PTK.

13. Kubota SS (1976): Cataract in fishes: Pathological changes in the lens. Fish Pathol, 10, 191-197.

14. Luna LG (1968): Manual of Histologic Staining Methods of the Armed Forced Institute of Pathology, 3.rd edition, McGraw-Hill Book Company, Newyork, Toronto, London, Sydney.

15. Markevic AP (1951): Parasitic fauna of freshwater fish of the Ukrainian SSR, Israel program for scientific translations, Jerusalem, 95-255.

16. Menzies FD, Crockford T, Breck O, et al. (2002): Estimation of direct costs associated with cataracts in farmed Atlantic salmon (Salmo salar). Bull Eur Ass Fish Pathol, 22, 27-32.

17. Mitchell CG (1996): Diplostomum. Aquaculture Information Series, No.17. The Scottish Office Agriculture, Environment and Fisheries Department. Marine Laboratory. Aberdeen.

18. Ozesen Ç (2011): The helminth community of the sand smelt (Atherina boyeri Risso, 1810) from Lake Iznik, Turkey. J Helminthol, 21, 1- 6.

19. Shariff M, Richards RH, Sommerville C (1980): The histopathology of acute and chronic infections of rainbow trout Salmo gairdneri Richardson with eye flukes, Diplostomum spp. J Fish Dis, 3, 455-465.

20. Turgut E, Ozgul G (2012): Seasonal changes and host size-dependent variation in Diplostomum spp. infection of some Cyprinid Fish. Pak J Zool, 44, 123-128.

Geliş tarihi: 02.07.2015/Kabul tarihi:16.10.2015

Address for correspondence:

Yrd. Doç. Dr. Meriç Lütfi AVSEVER

Aksaray Üniversitesi, Eskil Meslek Yüksek Okulu

Laboratuvar ve Veteriner Bilimleri

Eskil-Aksaray, Türkiye.

email:lutfiavsever@gmail.com 